\title{
Effective Removal of Cu(II) from Aqueous Solution using Acasia Arabica Tree Bark Sustrate
}

\author{
Gharde A. D. ${ }^{1}$, Gharde B. D. ${ }^{2}$
}

${ }^{1}$ Department of Chemistry, N. A. College, Umred Dist. Nagpur, Maharashtra, India

2 Department of Chemistry, Science Collage, Pauni Dist. Bhandara, Maharashtra, India

\section{ABSTRACT}

This work reports the characterization of intensive industrial and agricultural activity is the basic reason of enormous pollution of the environment. Heavy metals generally occur in water in low concentration as a result of metal industries and partly through geological processes, but these cause direct toxicity both to human and other living beings. Due to their presence obeyed the specified limit. Heavy metals in wastewater has emerged as focus of environment remediation efforts of industrialization, urbanization with new technological advantages. The natural bodies of water are polluted by means of different contaminant like organic refractories, heavy metal ions etc. The significant concentration of some of the heavy metal ions in water are toxic to human being, animals as well as aquatic organisms. Some heavy metal ions even at the trace level has been recognized toxic to the public health. Many metals have been evaluated toxic to aquatic life certain to threshold toxicity level. The effect of tree bark for $\mathrm{Cu}$ (II) from copper sulphate on the metal content of industrial wastewater was investigated in the $\mathrm{pH}$ of 4-6. It is observed that the method of binding follows the first order adsorption rate expression such as effect of $\mathrm{pH}$, agitation time, doses of bark substrate, initial metal ion concentration, effect of varying temperature were also studied.

Keywords : Acasia Arabica Tree Bark Substrate, Copper Removal, Column Study, Batch Study, Metal Ion, Spectrophotometer.

\section{INTRODUCTION}

Water reserve of the world are specific. The total amount of water on the earth is about $2.3 \times 10^{20}$ Gallan (1.35 Billon $\mathrm{KM}^{3}$ ). From this only 37 Millon of which 4-5 occurs in polar ice caps and glaciers. It is clear that a little amount of fresh water is available to human. This quantity of water which is available for human use, is also getting contaminated because of urbanization, industrialization and population explosion. The salts of various heavy metals and other potentially dangerous species are being discharged into the aquatic environment. Water containing vital concentration of some of the heavy metal ions are harmful to human being, animals as well as aquatic organisms. The toxicity of some heavy metal ions even at the trace level has been recognized with respect to the public health for many years. Metals such as mercury, lead, cadmium, copper and chromium are under this categories. Many metals have been evaluated as harmful in aquatic life at about certain toxicity level. Many industries may have specific waste problems where the particular metal ion is an important part of manufacturing process. The notable example are the high zinc wastes of various rayon manufacturing ground wood pulp production in newspaper print production. Similarly 
Cd and Ag may found in photographic porcelain, ceramic and pigment printing wastes.

The pollution is defined as the addition of the constituent to water, air or land, which adversely alter the natural quality of the environment. Pollution is an undesirable change in physical, chemical or biological characteristic of water, air and soil that may harmful effect, human, animal and plant life. Copper is one of the oldest metal known to man and each probably the first metal employed by him for useful purpose. Copper is found with sulphate deposited along with $\mathrm{Pb}, \mathrm{Cd}$ and $\mathrm{Zn}$. And is also considered as an important chlalcophile element. It is present in zinc concentrate, smelters and water in small quantities. Copper is found in enzyme capable of carrying oxygen. It is an essential nutrient not only for animal but also for plant and lower form of organisms. Copper has many results in Wilson's disease in which excess copper is deposited to the brain, liver, skin, pancreas and miochordium. Copper salts are used for control of biological growth in reservoir, water distribution pipes and catalyzing the oxidation of $\mathrm{Mn}, \mathrm{Cd}$ may enter into the water in a localized pipe systems due to corrosion of $\mathrm{Cu}$ containing alloys in pipe fitting. Symptoms of copper deficiency are loss of weight, microcytic hypochromic anemia, disturbance in ossification and impartment of collision formation. Toxic symptoms are hemolytic crisis, jaundice and neurological disturbances.

\section{METHODS AND MATERIAL}

This chapter deals with the experimental techniques employed for binding of metal ions with Acasia Arabica tree bark substrate. The Acasia arabica tree bark is dried and finally powdered in an electric grinding machine and sieved through mesh. $2 \mathrm{gm}$ of powder was treated with 20 part of aqueous formaldehyde solution (39\%) and five part by volume of $0.25 \mathrm{~N}$ Sulphuric acid. The whole mixture was stirred occasionally for 6 hours at $50^{\circ} \mathrm{C}$ and filtered. The residue was washed with double distilled water, the $\mathrm{pH}$ of this filtrate was $4-5$ till it is free from sulphuric acid and then dried in an electric oven at $60^{\circ} \mathrm{C}$ till it becomes moisture free and then powdered. It was then polymerized with formaldehyde in an acidic medium.

\section{Preparation and estimation of Copper Solution:}

Standard $0.0001 \mathrm{M}$ solution of Copper sulphate was first prepared by dissolving adequate amount of the salt in a $500 \mathrm{ml}$ volumentric flask with distilled water to the $10 \mathrm{ml} 0.001 \mathrm{M}$ Copper sulphate solution, $5 \mathrm{ml}$ of $25 \%$ Citric acid was added, $\mathrm{pH}$ about $4-5$ were mentained by additing ammonia solution. Excess of ammonia was removed by boiling. $15 \mathrm{ml}$ of 4\% EDTA solution as added to it. The content was transferred to separating funnel with addition of $10 \mathrm{ml} 0.2 \%$ aqueous solution of sodium diethyl dicarbamite solution when it was shaken for 1 minute. Yellow brownish colour was developed. $20 \mathrm{ml} \mathrm{n}$-butyl acetate was added into the funnel and shaken for 1 minute. The organic layer acquired the yellow colour. Two phases were separated after cooling the content, the lower aqueous layer was removed from it and $20 \mathrm{ml}$ of $5 \%$ sulphuric acid was added into it. The content was shaken for 15-20 seconds, cool an organic phase was separated. Absorbance was measured at $560 \mathrm{~nm}$ against a blank. All the copper was removed and extracted. The standard Beer's law curve for estimation of $\mathrm{Cu}(\mathrm{II})$ by this method was obtained by varying the concentration of $\mathrm{Cu}(\mathrm{II})$ ion solution. The graph of absorbance against concentration was plotted.

\section{RESULTS AND DISCUSSION}

The result and discussion are given under the relevant paragraph for $\mathrm{Cu}$ (II) metal ions with the Acasia arabica tree bark substrate. 


\section{Batch Method:}

\section{Effect of Agitation Time}

$100 \mathrm{ml}$ of $92.6 \mathrm{ppm}$ of metal solution was agitated with $1 \mathrm{gm}$ of Acasia arabica tree bark substrate for different time intervals varying from 5-240 minutes. It is evident from the data that the $\mathrm{Cu}$ (II) ion removal from solution within 5 minutes showing that the metal ion adsorption on the substrate was very fast. The $\mathrm{Cu}$ (II) ion removal from solution at 30 minutes, there after the \% removal remain constant. Hence, 30 minute contact time/ agitation time was fixed for further studies.

\section{Effect of $\mathrm{pH}$}

The effect of $\mathrm{pH}$ on the adsorption of $\mathrm{Cu}$ (II) ions in the solution has been studied when $1 \mathrm{gm}$ of substrate was agitated with $100 \mathrm{ml}$ of $\mathrm{Cu}$ (II) solution for 1 hour at room temperature. The $\mathrm{pH}$ was varied from $2.5-$ 9.5. It has been observed that adsorption of metal ions gradually increases up to certain extent and then decreases the sorption of $\mathrm{Cu}(\mathrm{II})$ ions. The final $\mathrm{pH}$ was found to be less than initial $\mathrm{pH}$.

\section{Effect of dosage of adsorbent}

Varying dosage of adsorbent of $100 \mathrm{ml}$ of metal ion solution with $5.5 \mathrm{pH}$ of $\mathrm{Cu}(\mathrm{II})$ ion solution agitated for 30 minutes. It is observed that the removal of metal ions increases with increase in dosage of adsorbent. However, $1 \mathrm{gm}$ of dose chosen for further studies.

Using the data Freundlich adsorption isotherm has been drawn by plotting log of $\mathrm{x} / \mathrm{m}$ vs log Ce, where $\mathrm{x} / \mathrm{m}$ is concentration of $\mathrm{Cu}$ (II) (adsorbed per gm. of adsorbent) and $\mathrm{Ce}$ is the residual concentration of metal ions.

\section{Effect of Temperature}

At different temperatures metal ions were adsorbed on the substrate. The temperature varying from 30$70^{\circ} \mathrm{C}$. It is observed that when $1 \mathrm{gm}$ substrate was agitated with $100 \mathrm{ml}$ of $\mathrm{Cu}$ (II) ion solution for 30 minutes. The adsorption was decreased with increase in temperature. Hence, all further studies were performed at room temperature.

\section{Effect of Initial Metal ion Concentration}

$100 \mathrm{ml}$ of metal ion solution was agitated with $1 \mathrm{gm}$ of substrate at $\mathrm{pH}$ of 5.5 for about 30 minutes at $30^{\circ} \mathrm{C}$. It was observed that metal ion removal from solution increases with increase in initial metal ion concentration. However, the \% of metal ion removal from solution would naturally decreases with increase of metal ion concentration.

\section{Column Studies on $\mathrm{Cu}$ (II) ions:}

Column adsorption of $\mathrm{Cu}(\mathrm{II})$ ions on Acasia arabica tree bark substrate at room temperature was investigated using aqueous solution of $92.6 \mathrm{ppm}$ and $5.5 \mathrm{pH}$ is faster and effective adsorption of $\mathrm{Cu}$ (II) ion occurred during the initial phase maximum. Adsorption occur within 40 minutes and up to $90 \mathrm{ml}$ subsequent adsorption decreases as a consequence of the progressive saturation of the binding sites.

\section{IV.CONCLUSION}

The work presented in this paper is very sincere attempt in this direction, though limited only to the field of removal of toxic metal ions and organic pollutants from industrial wastewater by using easily available and low cost natural polymeric substances of Acasia arabica tree bark substrate. The result of batch experiments and column studies prove that under appropriate experimental conditions, substantial quantities of the heavy metal ions in solution could be removed from solution by the modified natural polymeric substrate. Further if adequately packed column of this substrate are employed, the heavy metal ions present in solution could be attenuated to very low level. 
Table 1. Effect of Agitation time adsorption of $\mathrm{Cu}(\mathrm{II})$ using Acasia arabica bark substrate

\begin{tabular}{|c|c|c|c|c|c|}
\hline $\begin{array}{c}\text { Sr. } \\
\text { No. }\end{array}$ & $\begin{array}{c}\text { Time of } \\
\text { Agitation } \\
(\mathrm{min})\end{array}$ & $\begin{array}{c}\text { Initial } \\
\text { Conc. } \\
(\mathrm{ppm})\end{array}$ & $\begin{array}{c}\text { Final } \\
\text { Conc. } \\
(\mathrm{ppm})\end{array}$ & $\begin{array}{c}\text { Concentration } \\
\text { Adsorbed } \\
(\mathrm{ppm})\end{array}$ & $\begin{array}{c}\text { \% Removal of } \\
\mathrm{Cu}(\mathrm{II})\end{array}$ \\
\hline 1 & 5 & 92.6 & 69.50 & 23.10 & 24.94 \\
\hline 2 & 10 & 92.6 & 35.50 & 57.10 & 61.66 \\
\hline 3 & 15 & 92.6 & 33.96 & 58.64 & 63.32 \\
\hline 4 & 20 & 92.6 & 29.48 & 63.12 & 68.16 \\
\hline 5 & 60 & 92.6 & 29.48 & 63.12 & 68.16 \\
\hline 6 & 120 & 92.6 & 29.48 & 63.12 & 68.16 \\
\hline 7 & 240 & 92.6 & 29.48 & 63.12 & 68.16 \\
\hline
\end{tabular}

In each case $1 \mathrm{gm}$ of substrate was agitated with $100 \mathrm{ml} \mathrm{Cu(II)}$ ion solution at $\mathrm{pH} 5.5$

Table 2. Effect of $\mathrm{pH}$ on adsorption of $\mathrm{Cu}(\mathrm{II})$ using Acasia arabica bark substrate

\begin{tabular}{|c|c|c|c|c|c|c|c|}
\hline $\begin{array}{c}\text { Sr. } \\
\text { No. }\end{array}$ & $\begin{array}{c}\text { Initial } \\
\mathrm{pH}\end{array}$ & $\begin{array}{c}\text { Final } \\
\mathrm{pH}\end{array}$ & $\begin{array}{c}\text { Initial } \\
\text { Conc. } \\
(\mathrm{ppm})\end{array}$ & $\begin{array}{c}\text { Final } \\
\text { Conc. } \\
(\mathrm{ppm})\end{array}$ & $\begin{array}{c}\text { Cond. } \\
\text { Adsorbed } \\
(\mathrm{ppm})\end{array}$ & $\begin{array}{c}\text { \% Removal } \\
\text { of Cu(II) }\end{array}$ & \\
\hline 1 & 2.5 & 2.4 & 92.6 & 52.11 & 40.49 & 43.72 & \\
\hline 2 & 3.5 & 3.2 & 92.6 & 40.23 & 52.37 & 56.55 & \\
\hline 3 & 4.5 & 4.3 & 92.6 & 30.95 & 61.65 & 66.57 & \\
\hline 4 & 5.5 & 5.2 & 92.6 & 25.17 & 67.43 & 72.81 & \\
\hline 5 & 6.5 & 6.2 & 92.6 & 50.34 & 42.26 & 45.63 & \\
\hline 6 & 7.5 & 7.2 & 92.6 & 61.44 & 31.16 & 33.64 & \\
\hline 7 & 8.5 & 8.1 & 92.6 & 69.50 & 23.10 & 24.94 & \\
\hline 8 & 9.5 & 9.2 & 92.6 & 73.76 & 18.84 & 20.34 & \\
\hline
\end{tabular}

In each case $1 \mathrm{gm}$ of substrate was agitated with $100 \mathrm{ml} 92.6 \mathrm{ppm}$ solution of $\mathrm{Cu}$ (II) ion for 30 minutes at room temperature

Table 3. Effect of Dosages on adsorption of $\mathrm{Cu}(\mathrm{II})$ using Acasia arabica bark substrate

\begin{tabular}{|c|c|c|c|c|c|}
\hline $\begin{array}{c}\text { Sr. } \\
\text { No. }\end{array}$ & $\begin{array}{c}\text { Substrate } \\
\text { Dosages } \\
(\mathrm{gm})\end{array}$ & $\begin{array}{c}\text { Initial } \\
\text { Conc. } \\
(\mathrm{ppm})\end{array}$ & $\begin{array}{c}\text { Final } \\
\text { Conc. } \\
(\mathrm{ppm})\end{array}$ & $\begin{array}{c}\text { Cond. } \\
\text { Adsorbed } \\
(\mathrm{ppm})\end{array}$ & $\begin{array}{c}\text { \% Removal of } \\
\text { Cu(II) }\end{array}$ \\
\hline 1 & 0.5 & 92.6 & 57.62 & 34.98 & 37.77 \\
\hline 2 & 1.0 & 92.6 & 46.87 & 45.73 & 49.38 \\
\hline 3 & 1.5 & 92.6 & 45.17 & 47.43 & 51.21 \\
\hline 4 & 2.0 & 92.6 & 40.23 & 52.37 & 56.55 \\
\hline
\end{tabular}




\begin{tabular}{|l|l|l|l|l|l|}
\hline 5 & 2.5 & 92.6 & 35.50 & 57.10 & 61.66 \\
\hline 6 & 3.0 & 92.6 & 30.95 & 61.65 & 66.57 \\
\hline 7 & 3.5 & 92.6 & 25.17 & 67.43 & 72.81 \\
\hline 8 & 4.0 & 92.6 & 21.01 & 71.59 & 77.30 \\
\hline
\end{tabular}

In each case $100 \mathrm{ml} 92.6 \mathrm{ppm} \mathrm{Cu(II)}$ ion solution at $\mathrm{pH} 5.5$ was agitated for $30 \mathrm{~min}$. at $30^{\circ} \mathrm{C}$

Table 4. Freundlich Adsorption Isotherm for adsorption of $\mathrm{Cu}(\mathrm{II})$ using Acasia arabica bark substrate

\begin{tabular}{|c|c|c|c|c|c|c|}
\hline $\begin{array}{c}\text { Sr. } \\
\text { No. }\end{array}$ & $\begin{array}{c}\text { Substrate } \\
\text { Dosages } \\
(\mathrm{gm})\end{array}$ & $\begin{array}{c}\text { Initial } \\
\text { Conc. } \\
(\mathrm{ppm})\end{array}$ & $\mathbf{x} / \mathrm{m}$ & $\log (\mathrm{x} / \mathrm{m})$ & $\begin{array}{c}\text { Equilibrium } \\
\text { Conc. (Ce) }\end{array}$ & $\log \mathrm{C}_{\mathrm{e}}$ \\
\hline 1 & 1 & 73.76 & 47.17 & 1.67 & 26.59 & 1.42 \\
\hline 2 & 1 & 78.18 & 50.16 & 1.70 & 28.02 & 1.44 \\
\hline 3 & 1 & 85.16 & 48.11 & 1.68 & 37.05 & 1.56 \\
\hline 4 & 1 & 92.60 & 50.75 & 1.70 & 41.85 & 1.62 \\
\hline 5 & 1 & 100.57 & 50.23 & 1.70 & 50.34 & 1.70 \\
\hline 6 & 1 & 109.94 & 51.52 & 1.71 & 57.62 & 1.76 \\
\hline 7 & 1 & 118.42 & 53.01 & 1.72 & 65.40 & 1.81 \\
\hline 8 & 1 & 132.11 & 53.92 & 1.73 & 78.18 & 1.89 \\
\hline 9 & 1 & 143.59 & 55.99 & 1.74 & 87.59 & 1.94 \\
\hline 10 & 1 & 156.37 & 55.80 & 1.74 & 100.57 & 2.00 \\
\hline
\end{tabular}

Table 6. Effect of initial metal ion concentration on the adsorption of $\mathrm{Cu}(\mathrm{II})$ using Acasia arabica bark substrate

\begin{tabular}{|c|c|c|c|c|}
\hline Sr.No & $\begin{array}{c}\text { Initial } \\
\text { Conc. } \\
(\mathrm{ppm})\end{array}$ & $\begin{array}{c}\text { Final } \\
\text { Conc. } \\
(\mathrm{ppm})\end{array}$ & $\begin{array}{c}\text { Cond. } \\
\text { Adsorbed } \\
(\mathrm{ppm})\end{array}$ & $\begin{array}{c}\text { \% Removal of } \\
\text { Co(II) }\end{array}$ \\
\hline 1 & 73.76 & 26.59 & 47.17 & 63.95 \\
\hline 2 & 78.18 & 28.02 & 50.16 & 64.15 \\
\hline 3 & 85.16 & 37.05 & 48.11 & 56.49 \\
\hline 4 & 92.60 & 41.85 & 50.75 & 54.80 \\
\hline 5 & 100.57 & 50.34 & 50.23 & 49.94 \\
\hline 6 & 109.94 & 57.62 & 51.52 & 47.20 \\
\hline 7 & 118.42 & 65.40 & 53.01 & 64.76 \\
\hline 8 & 132.11 & 78.18 & 53.92 & 40.81 \\
\hline 9 & 143.59 & 87.59 & 55.99 & 38.99 \\
\hline 10 & 156.37 & 100.57 & 55.80 & 35.68 \\
\hline
\end{tabular}


In each case $1 \mathrm{gm}$ of substrate was agitated with $100 \mathrm{ml} \mathrm{Cu}(\mathrm{II})$ ion solution at $\mathrm{pH} 5.5$ for $30 \mathrm{~min}$ at $30^{\circ} \mathrm{C}$

Table 5. Effect of Temperature on adsorption of $\mathrm{Cu}(\mathrm{II})$ ions using Acasia arabica tree bark substrate

\begin{tabular}{|c|c|c|c|c|c|}
\hline $\begin{array}{c}\text { Sr. } \\
\text { No. }\end{array}$ & $\begin{array}{c}\text { Temperature } \\
\left({ }^{\circ} \mathrm{C}\right)\end{array}$ & $\begin{array}{c}\text { Initial } \\
\text { Conc. } \\
(\mathrm{ppm})\end{array}$ & $\begin{array}{c}\text { Final } \\
\text { Conc. } \\
(\mathrm{ppm})\end{array}$ & $\begin{array}{c}\text { Cond. } \\
\text { Adsorbed } \\
(\mathrm{ppm})\end{array}$ & $\begin{array}{c}\% \text { Removal of } \\
\mathrm{Cu}(\mathrm{II})\end{array}$ \\
\hline 1 & 30 & 92.60 & 30.95 & 61.65 & 66.57 \\
\hline 2 & 50 & 92.60 & 52.11 & 40.49 & 43.72 \\
\hline 3 & 70 & 92.60 & 73.76 & 18.84 & 20.34 \\
\hline
\end{tabular}

In each case $1 \mathrm{gm}$ of substrate was agitated with $100 \mathrm{ml} 92.6 \mathrm{ppm} \mathrm{Cu}$ (II) ion solution at $\mathrm{pH} 5.5$ for 30 minutes

Table 6. Adsorption of $\mathrm{Cu}(\mathrm{II})$ ions usingPacked column of Acasia arabica tree bark substrate

\begin{tabular}{|c|c|c|c|c|c|c|}
\hline $\begin{array}{c}\text { Sr. } \\
\text { No. }\end{array}$ & $\begin{array}{c}\text { Time } \\
\text { (minutes) }\end{array}$ & $\begin{array}{c}\text { Throwpot } \\
\text { Volume } \\
(\mathrm{ml})\end{array}$ & $\begin{array}{c}\text { Initial } \\
\text { Conc. } \\
(\mathrm{ppm})\end{array}$ & $\begin{array}{c}\text { Final } \\
\text { Conc. } \\
(\mathrm{ppm})\end{array}$ & $\begin{array}{c}\text { Conc. } \\
\text { Adsorpbed } \\
(\mathrm{ppm})\end{array}$ & $\begin{array}{c}\text { \% Removal } \\
\text { of Cu(II) }\end{array}$ \\
\hline 1 & 5 & 10.4 & 92.60 & 69.50 & 23.10 & 24.94 \\
\hline 2 & 10 & 20.8 & 92.60 & 63.40 & 29.20 & 31.53 \\
\hline 3 & 15 & 31.2 & 92.60 & 57.62 & 34.98 & 37.77 \\
\hline 4 & 20 & 52.0 & 92.60 & 53.92 & 38.68 & 41.77 \\
\hline 5 & 25 & 62.4 & 92.60 & 48.59 & 44.01 & 47.52 \\
\hline 6 & 30 & 72.8 & 92.60 & 41.85 & 50.75 & 54.80 \\
\hline 7 & 35 & 83.2 & 92.60 & 37.05 & 55.55 & 59.98 \\
\hline 8 & 40 & 93.6 & 92.60 & 33.96 & 58.64 & 63.32 \\
\hline 9 & 45 & 104.0 & 92.60 & 35.50 & 57.10 & 61.66 \\
\hline 10 & 50 & 114.4 & 92.60 & 40.23 & 52.37 & 56.55 \\
\hline 11 & 55 & 124.8 & 92.60 & 45.17 & 47.43 & 51.21 \\
\hline 12 & 60 & 135.2 & 92.60 & 50.34 & 42.26 & 45.63 \\
\hline 13 & 65 & 145.6 & 92.60 & 53.92 & 38.68 & 41.77 \\
\hline 14 & 70 & 156.0 & 92.60 & 57.62 & 34.98 & 37.77 \\
\hline 15 & 75 & 166.4 & 92.60 & 59.55 & 33.09 & 35.73 \\
\hline
\end{tabular}




\section{Figures}

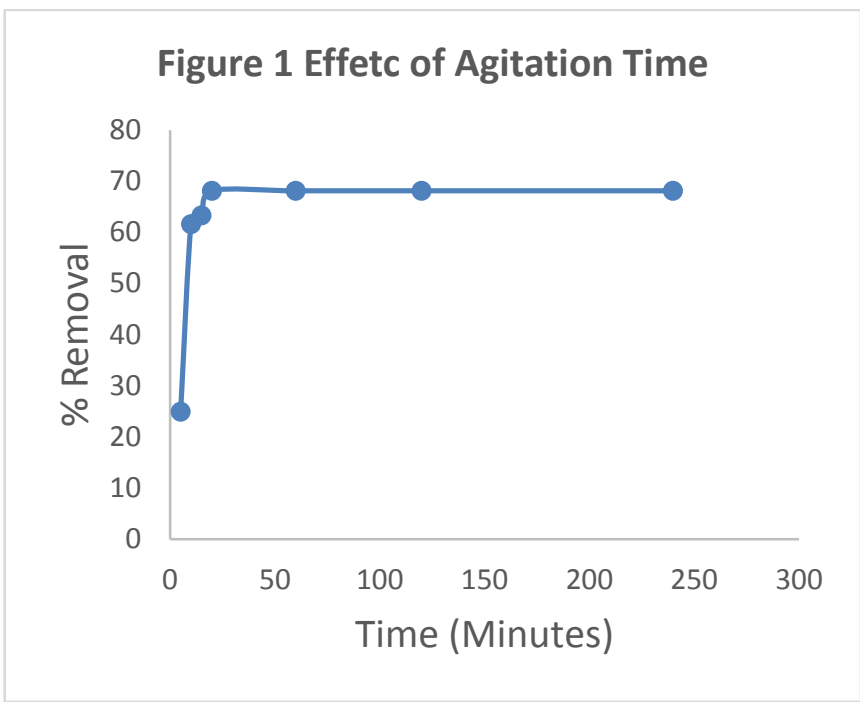

\section{Figure 4 Freundlich Adsorption Isotherm}
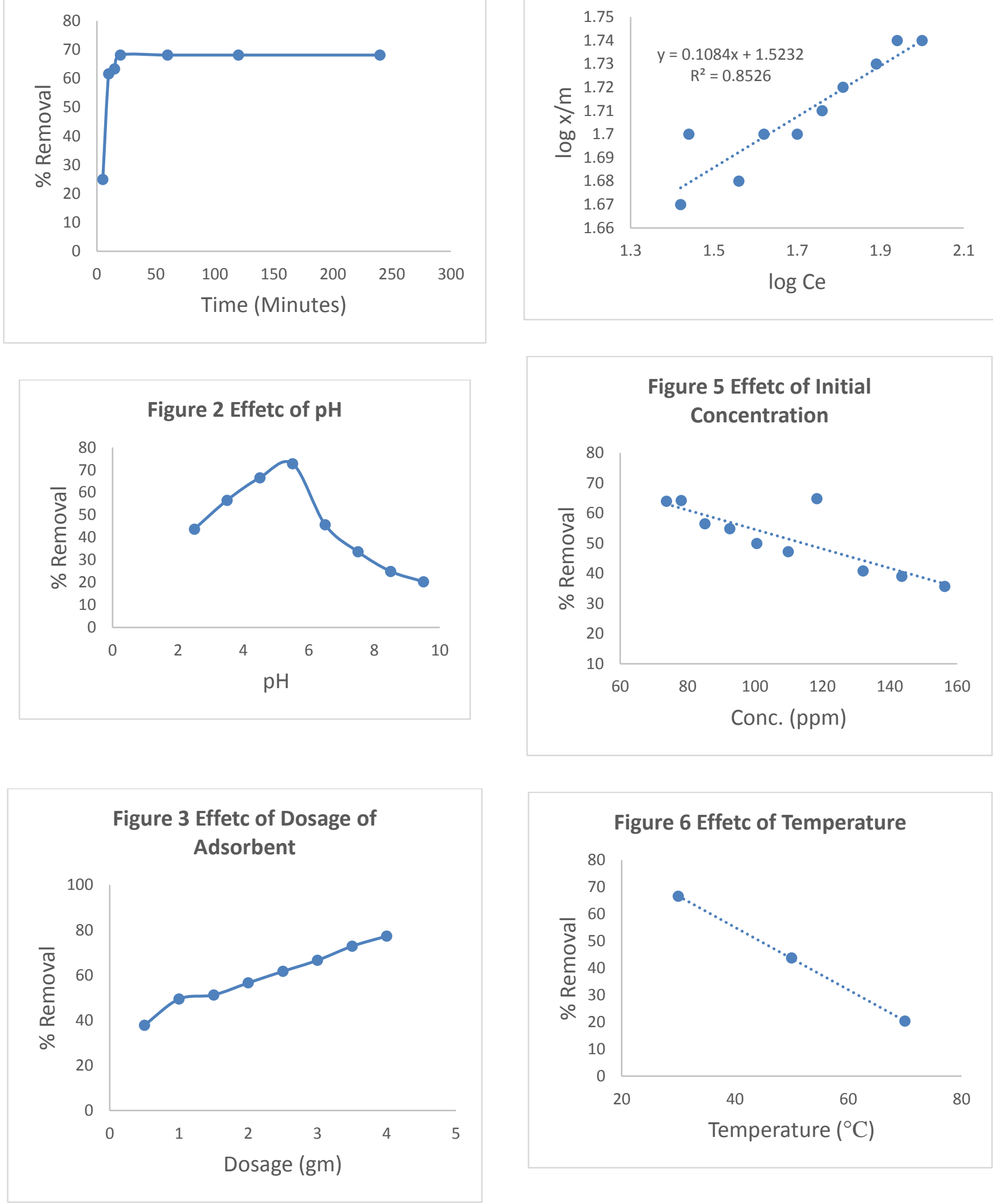


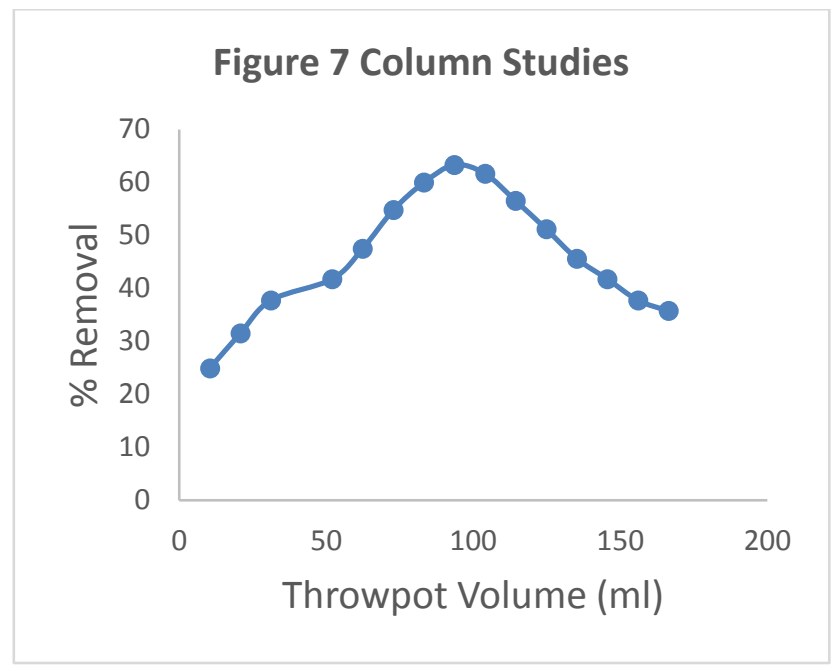

\section{REFERENCES}

[1]. Aderhold D., Willians C.J., Edyvean R.G., "The removal of heavy metals ions by seaweeds and their derivative" Bioresour. Technol. 58(1), 1-6, 1996.

[2]. Ahalya N., Ramachandra T.V., Kanamadi R.D. “ Biosorption of heavy metals " Res. J. Chem. Environ., 7, 71-79, 2003.

[3]. Amarsinghe B.M.W.P.K, Willins R.A., "Tea waste as low cost adsorbent for the removal of $\mathrm{Cu}$ and $\mathrm{Pb}$ from wastewater" Chemical Engineering Journal, 132, 299-309, 2007.

[4]. Annadurai G., Jung R.S., Lee D.J. “Adsorption of heavy metals from wastewater using banana and orange peels" Water Sci. Technol. 47 (1),185-190,2003.

[5]. Asraf M.A., Maah M.J. and Yusoff L., "Study of mango biomass as cationic biosorbent" Int. J. Environ. Sci. Tech., 7(3), 581-590, 2010.

[6]. Balsubramaniam A., Chadrshkh Era G.E., Ahmad A.J. "Copper removal of Azdirachta indica" J. Ecotoxicology and Env. Monitoring” 8(1), 59, 64,1998.

[7]. Ashraf Mohmmad Aqueel, "Removal of heavy metals from aqueous solution by using mango biomass"
[8]. African Journal of Biotechnology, 10(1), 21632177, 2011.

[9]. Bankar D.B. AND Dara S.D., “ Binding of copper ion with modified green Phyllanthus embica leaves" Journal of IPHE, India,4, 5965.1983.

[10]. Dani S.P. and Dara S.S., "Use of modified corn starch for the recovery of $\mathrm{Pb} 2+, \mathrm{Cu} 2+$ and Zn2+ from waste water, Journal of IPHE, India, 4, 47-54,1983

[11]. Dronnet V.M., Renard M.G.C., Axelos M.A.V. and Thibult J.F. Binding of divalent metal cation such as Cobalt, Copper, Nickel by sugar beet pulp carbohydrate" Polymer 34(1-2), 7382, 1997.

[12]. Gharde B.D. "Removal of $\mathrm{Cu}(\mathrm{II})$ and $\mathrm{Ni}(\mathrm{II})$ from aqueous solution using Tectona grandis bark substrate" Oriental Journal of Chemistry, 26(1), 175-180, 2010.

\section{Cite this article as :}

Gharde A. D., Gharde B. D., "Effective removal of $\mathrm{Cu}$ (II) from aqueous solution using Acasia Arabica tree bark sustrate", International Journal of Scientific Research in Science and Technology (IJSRST), Online ISSN : 2395-602X, Print ISSN : 2395-6011, Volume 7 Issue 2, pp. 97-104, March-April 2020. Available at doi : https://doi.org/10.32628/IJSRST207228

Journal URL : http://ijsrst.com/IJSRST207228 